\title{
THE CHIMERA OF CONSERVATION IN PAPUA NEW GUINEA AND THE CHALLENGE OF CHANGING TRAJECTORIES
}

\section{Phil Shearman}

University of Papua New Guinea, Papua New Guinea
Papua New Guinea (PNG) is an exception from the many stories of Southeast Asian conservation challenges for the simple reason that it is perhaps 20 years behind other countries in the process of liquidating its environmental capital - its forests, clean rivers, and healthy seas - and transforming them into portable financial capital. It is in a comparatively marvelous condition; approximately $70 \%$ of the country is forested, it has little in the way of a polluting manufacturing sector, and its population density is overall quite low. Currently, the population is 7 million people, but it is projected to nearly double to 13.3 million by midcentury (Population Reference Bureau, 2012); efforts to alleviate poverty and a desire for increased standards of living, coupled with high overseas demand for such products as wood and minerals are likely to accelerate the destruction of natural communities in the coming decades. PNG has a massive biotic diversity that has originated as a product of a series of mountain-building events and island arcs speciations sandwiched sequentially onto the main islands. While some of the largest river systems have been polluted by the spoils of the mining industry, most of the smaller rivers remain undammed and clean. However, things are now chang- ing fast. The logging industry has been through much of the accessible lowlands and is now grasping for re-entry permits, or, worse still, rights to clear-cut forested lands. The population is growing rapidly, as we have seen, putting stresses on what are partly collapsed health, transport, and education sectors. And there is barely a region of the country that has not been allocated to mining exploration with a slew of new mines under development. There are challenges aplenty on the conservation horizon. For a long while, financial capital was afraid of the risks of PNG, but now a chink in the levee has opened and money-seeking "growth" is flooding in.

PNG is a country that is becoming wealthier but at the same time becoming substantially more corrupt. This has far-reaching implications for the practicalities and potential for conservation or for responsible environmental management. In the future, PNG could well become a textbook example of the "Dutch Disease," the condition under which economies that are based principally on the extraction and sale of raw resources are prone to corruption, mismanagement, and inflation. In the recent Transparency International index of corruption (Transparency International, 2012), PNG was 
ranked 150 out of 176 , and the situation is rapidly deteriorating still further. PNG as a nation "State" in the common sense of the word does not really exist. It is governed under a parliamentary democracy, with a Prime Minister as the elected head of government, and a Governor General as the head of State. In late 2010, the country had no head of government after the Prime Minister was suspended on account of a corruption investigation. Additionally, it had no Deputy Prime Minister or Governor General on account of breaches of the constitution. Indeed, there was really no government in the normal sense of the word, yet for the majority of people its absence will have gone unnoticed. Government interaction with most people is scarce or even non-existent. Most people describe themselves by their language group, of which there are somewhere in the order of 850 , and within those groups are further divisions of clans and families. Clan and tribal ties are far more important in most societal roles than any other factor. The "wantok" ("belonging to my language") system is the network through which resources and patronage flow most freely. It is hard to say no to a "wantok" and if you are in a position of influence, power, or finance it is hard to avoid being persuaded into using that influence for the benefit of your kin. While this system is certainly one of the key factors that has dragged the country to the bottom quintile of all the corruption indices, it is also the system whereby many people are fed, clothed, and schooled. If the wantok system were to disappear one morning, there would be many more hungry mouths by nightfall.

The need for conservation in most of its interpretations is based on the notion of scarcity, at present or in the future. But for most PNG people this idea is largely an alien one. If one asks a villager about the population of an animal that he has rarely if ever seen, the usual answer is "planti I stap!" - there are plenty of them out there - yet on more careful questioning it might be revealed that the species has not been seen or caught for rather a long time. This might be partly based on the restricted range of most human groups over much of their 60,000-year presence on these islands. Rugged topography reduces the spaciousness of people's outlook; it creates an insularity of sorts, and most rural villages are surrounded by a sea of mountains rather than water. I have visited many remote villages where most people have never been out of their valley system. When you are surrounded by steep mountains cloaked in forest, it must be easy to imagine that the forest goes on forever, even though people live in and have cleared the neighboring valleys. The wonder in a villager's eyes when he can see his terrain in a satellite photo, or in some cases from the window of a small plane, is a sight to behold. It is only then that he realizes that the forest does not go on forever. Conservation in most Western interpretations is not overly relevant to PNG people, because most human-environment interactions at the village or valley scale are not limited by scarcity. Therefore, the challenge for Western conservation paradigms in PNG is that most people are not concerned with environmental issues because the ecosystems in which they live are still intact.

Many Papua New Guineans are brilliant bushmen, and their ability to travel through and survive in the jungle is awe-inspiring. But it has to be. In much of the mountainous interior, survival does not come easily. Protein has been and continues to be in common shortage, with few big animals and low densities of game. Nonetheless, most rural Papua New Guineans consume much of their protein from bushmeat; an estimated 4 to 8 million vertebrate animals, or 10-20 thousand tonnes of biomass, are captured to support the rural population each year, with much of it consisting of small animals (Mack and West, 2005). Nothing is too small to eat. Many populations of animals are likely to be under significant pressure in all but the most remote places. About two-thirds of PNGs forest is within a day's walking distance from a village. But it also suggests that some notions of conservation, in this case voluntarily relinquishing the option to eat meat, is not a luxury that most Papua New Guineans have. They generally do not see their environment as something that needs to be protected from their actions - for most, the opposite would ring true. The environment is something from which food is won, that is fought back to clear areas for gardens or that is the domain of snakes, spirits, and disease.

Historically, the boundaries between different tribal groups were always contested places, and outbreaks of hostilities were and still are common. Especially in the highlands, payback and compensation are perennial parts of life. As an aside, I have often suspected that some forested but contested grounds, commonly running along the spines of mountain ranges, would be the simplest areas to "protect" in a concept akin to the peace parks that have been promoted around the world to soothe such borders. But it also means that the notion of expansive "environmental protection" being something of a common good is an alien concept - 
what counts is what is good for the clan or tribe. In the early 1990s, I was shocked to see the relish with which landowners from the environs of the Porgera gold mine learned about the problems the discharge of tailings into the river system was causing people living downstream. The affected communities were of a different tribe with whom the Porgerans had long-held enmity, so hearing of their plight was not unwelcome news. In a perhaps more humorous example, in the 1980s the Amazonian weed Eichornia crassipes spread up the Sepik River far faster than had been expected. Groups hostile to each other were deliberately seeding their neighbors' waterways so that they too could suffer from the same problems - a form of low-tech biological warfare. The conservation ethic is one foreign to the rural people of PNG.

Although local people are still clearing substantial areas of forest for gardening purposes or via deliberate use of fire, there is little prospect of limiting this behavior. Nor is there perhaps, from a conservation perspective, a convincing rationale for attempting to do so. Local people in PNG place one of the most minimal per capita impacts on the global environment of most people on the planet. But more critically, pretty much everything that can be done that is within the inventory of reasonable external intervention to ameliorate the impact of subsistence activities can only, at best case, have no impact - but in most cases will actually make such impacts greater. Anything that increases potential future rents from deforestation, such as realizing increased yields through intensification, is likely to increase, not decrease, deforestation. In regard to recent discussions on the UN's Reducing Emissions from Deforestation and Forest Degradation (REDD) programme, the very act of having a carbon market competing with the international wood and agricultural markets, in the absence of concerted policies aimed at reducing global consumption, and in the absence of a functional tropical government willing and able to enforce compliance, will translate into more agricultural and logging related deforestation - because they become more profitable (Angelsen, 1999).

In PNG, environmental despoliation tends to follow a trend of punctuated equilibria - long periods of apparent stasis, or incremental loss, followed by brief periods of major change. An example is the El Niño fires of 1997-1998 and 2002 that destroyed $15 \%$ of the country's sub-alpine forests and impacted large areas of lowland forest (Shearman and Bryan, 2011). Forest loss in the next El Niño is likely to be very signifi- cant indeed, especially now that huge areas have been primed for conversion by logging activity. What is accelerating, however, is the number and intensity of industrial resource exploitation projects throughout the country. Old growth logging, agroforestry, and mining, in part facilitated by corruption within the government, all demand consideration as key drivers of the changes now occurring across the country.

The logging industry deserves the gold medal in this group for despoiling so much forest - simplifying forest structure, reducing its biomass and diversity while predisposing it to conversion - but also for its role in giving the country its first decent push on the roller coaster of corruption. ${ }^{1}$ It was in this sector that corruption gained its foothold, and from there it spread out until it became a systemic infection. The jockeying for government positions that could intercept the favor of the industry still continues, although now has become so institutionalized that it barely gets discussed. This is also perhaps because the other daily scandals appear to be occurring in increasing orders of magnitude relative to those of the loggers. In short, the forest industry has led the way in dropping the trajectory of development away from maximizing benefit across PNG society and firmly towards short-term outlooks, local self-interest, and ingrained corrupt practices.

As the unlogged areas become fewer and are restricted to more remote and inaccessible terrain, the industry is increasingly sourcing lumber by re-entering previously logged areas, a practice that is intensely damaging to regeneration - as well as illegal. While the logging code of practice stipulates that an area can be logged only once in a 35-year rotation, some areas have now been logged three times within 20 years. The pressure to cut corners is not just coming from the industry or from the revenue demands of government: it is also coming from forest owners themselves. With many rural communities dependent on logging companies for most of their revenue, employment, and basic services (and so very basic they are), the evaporation of timber landowners' royalties as the big trees are finished comes as a shock, and this is a catalyzing call for re-logging or, more catastrophically, for conversion into agroforestry projects.

Agroforestry in PNG includes many new projects, which to date have little to do with agriculture and lots

\footnotetext{
${ }^{1}$ The loggers have been in at least half the accessible forests, and almost all of those possessing high timber volumes.
} 




Figure 23.1 There is barely a square kilometer of PNG that is not covered by one or more extractive leases, whether they be for oil or mineral exploration, timber extraction, or, more recently, agroforestry projects. This map shows the coverage of these resource concessions. Most areas have at least one concession, but huge swathes have two or more, now including the sea-floor where an enterprising firm plans to start strip-mining hydrothermal vents. What will be left to apply to human development in 50 years when the revenue from these projects has been squandered or misappropriated?.

to do with circumventing the Forestry Act to gain cheap access to hardwoods, and, in the medium term, land. Collusion between the Department of Agriculture and Livestock, and the Department of Environment and Conservation (DEC) has seen the massive use of loopholes to obtain agriculture leases and, in turn, forest clearance licenses. As much as $15 \%$ of the country now sits within 99-year agricultural leases that legally strip the local traditional owners' use rights for three generations. While most of these leases, mostly given to Asian firms with little if any capital or experience, would never stand up to legal scrutiny, competent lawyers are prohibitively expensive for villagers. It is likely that these leases will remain in place and will be on-sold repeatedly until they do end up in the hands of those with sufficient capital to develop agroforestry projects. It is land alienation by stealth, and, given its extent, has the distinct possibility of resulting in huge clearances of forests.

Then there are the miners being granted exploration licenses over pretty much every square inch of the country with the apparent intent by the Government of mining every deposit at once (see Figure 23.1). Five major rivers are now seriously polluted with mining wastes, and many more are about to follow suit. ${ }^{2}$ Yet no one in Government circles has said:

\footnotetext{
${ }^{2}$ The Panguna Copper Mine (Bougainville Copper Ltd) polluted the Jaba River, the Ok Tedi Mine the Ok Tedi and Fly Rivers, the Porgera Gold Mine the Lagaip and Strickland Rivers, the Tolokuma Gold Mine the Angabanga River, and the recent Hidden Valley mine in Morobe has dumped large amounts of potentially acid-forming overburden into the Watut/Markham river system.
} 
[O]ur economy cannot handle all of these projects at once, we don't have near enough skilled people as a result of dutifully ignoring the education sector, and we will kick off frightening inflation as our economy has no depth - so why don't we just have a couple of massive projects, rather than permitting all at once?

The most recent example of the collusion between Government leaders and industrial developers at the expense of the national good is the allocation of the vast Ramu nickel deposit in Madang province to a largely state-owned Chinese company MCC (China Metallurgical Group Corporation). The agreement between the Somare Government and the Chinese exempts the company from paying taxes or royalties and allows them to bring in all their workers from Guangdong and Fujian. With virtually no revenue being generated for PNG, and no employment for its citizens, it is difficult to understand why anyone would agree to the project at all.

Over the past decade, the failure of DEC to mitigate, control, or regulate the extractive sectors, far less to examine holistic land management regimes, has been tragic. This is despite a massive injection of international funds on account of PNG's charismatic fauna and intact ecosystems. Donors and their consultants have congregated around DEC like polychaetes on an abyssal hydrothermal vent. In most developing countries, one can expect mining and agriculture departments to be somewhat laissez-faire with environmental issues, but then look towards environment departments to restore some balance. Not so in PNG. Here in the late 1990s, DEC ceased supporting all protected areas in the country. National parks were "handed back" to the local people with no accompanying finance. This was done citing insufficient revenue in spite of the fact that large sums were spent on international travel. This trend continued throughout the 2000s with DEC staff being directed not to process new applications for Wildlife Management Areas (WMAs) in areas that were likely to be of interest to the logging industry. ${ }^{3}$ It is serious when senior staff from mining or forestry departments write to DEC appealing to them to

\footnotetext{
${ }^{3}$ While the designation of an area as a Wildlife Management Area (WMA) does not exclude logging or mining from taking place within its borders, there is the perception in corners of industry that it could make their activities more difficult.
}

use their legislative power to rein in resource projects, or to take up conservation set asides - but to no avail. No, senior DEC staff consider that their job is to facilitate development - making sure the environmental laws are not an impediment to any project - even going to the length of changing the laws if necessary, with a helping hand from industry.

Emasculating the water quality schedules in the early 2000s was a severely retrograde step, but this was minor in comparison to the recent "veto-on-demand" amendments to the Environment Act, written by MCC's lawyers and illegally run through Parliament in 2010 to allow for millions of tons of tailings to be pumped into the sea. This occurred in response to a legal challenge initiated by landowners disputing the government's issuance of permits to the Ramu Nickel (MCC) operation to undertake Submarine Tailings Discharge (STD) off the coast near Madang. It was the miner's own lawyers who wrote the laws and handed them to the government to pass through Parliament. These laws gave one man, the Secretary of DEC, the power to exempt any project from the environmental protection laws and any need to compensate local people (or the State) for "unexpected" impacts, should the development be deemed by the same man as in the national interest. ${ }^{4}$ Surely this should get an international award for prostituting one's country to international capital? Thankfully, in early 2012, the O'Neill-Namah Government overturned this amendment, thus removing these powers.

On this particular issue, with its massive ramifications for all aspects of environmental protection, the big three international conservation groups were noticeably silent. Not a squeak was heard from them about this. Apparently this is because they did not wish to jeopardize their relationship with the PNG government, but, if true, this could only be for two reasons either they are doing so much good that on balance it would be foolish to put their achievements at risk, or

\footnotetext{
${ }^{4}$ The Environment Act Amendment Bill (2010) removes the rights of landowners to mount any legal challenge against any mining or development application approved by the government; it infers that environmental damage will happen in the course of doing business as an inevitable consequence of business, and explicitly excuses corporations from damage, removing any responsibility or obligation for clean-up and restoration or recompense.
} 
alternatively because they are raising so much money on behalf of their projects in PNG that they have become afraid of the tap being turned off if matters get rough.

It is with regret to come to the conclusion that, in PNG at least, these conservation groups have become little more than a business model, a model predicated on the periodic need for "new" exotic areas, the protection of which they can sell to amnesic donors. "New" areas are needed, not because the "old" ones have been protected, but because the old areas are now no-go zones for conservation organizations because of project-related disputes with local people, provincial governments, or the donors themselves, or just the need for new projects to sell. ${ }^{5}$ Very few of the areas these groups were involved with a decade ago still have their presence; far fewer have been conserved. Nor has the expenditure of massive amounts of cash transformed these regions into State-backed conservation initiatives, partly perhaps because there are none of them. PNG has little if anything to show for the rivers of cash that have been poured into these large conservation "firms." In this reconciliation, some of the analyses that have been undertaken in the field of "prioritization" need to be included.

In most countries, what is commonly "conserved," and by this I mean put into some form of protected area and managed by the state, is what is left at the end of the steep bit of a development trajectory - the mountainous bits, the infertile regions, the deserts. Conservation in PNG has been haunted by the spurious goal that the end point of conservation effort is the protection of the "right" bits. Make no mistake - if at some time in the future this country has managed to transition from $70 \%$ to $10-20 \%$ forest cover, even if this is in protected areas, it has failed in some really intrinsic ways. What are the "right bits" anyway? Those that are "representative," as if we are trying to turn a hierarchical web of systems into a set of living museum specimens, or those that enclose as much biodiversity in as small an area as possible, or contain some charismatic, flagship, rare, sexy species? A common theme is their

\footnotetext{
${ }^{5}$ The chapter titled "Fiasco" in the book Conservation Refugees, The Hundred-Year Conflict between Global Conservation and Native Peoples by Mark Dowie (The MIT Press, Cambridge, MA, 2009) describes a text-book example of such a problem.
}

presence in relatively small discrete locations, out of the way of development. ${ }^{6}$

Over the years, a suite of unimplementable, mapbased studies have proposed various smatterings of protected areas (PAs) as a worthy future target. I have difficulty with the paradigm that underpins this work, and that is not because we just do not have, nor will we have, sufficient biological knowledge to make these calls at any time in the relevant future (see Figure 23.2). Nor is my concern that, if only $10 \%$ of the country remains ecologically intact in a hundred years, these final locales will quickly be destroyed or degraded. ${ }^{7}$ My reticence at new rounds of target setting is also not principally because the ecological processes that maintain this country in a fundamental sense cannot survive such a reduction without being massively compromised and cease to support these PAs. My disquiet occurs because these exercises display such an impoverished vision of the potential that PNG still holds to not end up like other countries. Is it not possible for PNG to develop its human potential, to increase living standards without following the same path of ecological destruction as other countries?

A major problem with map-based prioritization exercises aimed at protecting "the best bits" is that, in a political environment in which implementation is not and could not be entertained, these plans get used by industrial players to justify the negative environmental consequences of their activity. Many a time, I have had an argument with one of the proponents of despoilation whose defense goes something like, "What is the problem if we trash this place, it is not a 'high conservation area,' a 'priority resource management unit,' or 'hotspot,' or 'ecoregion'” ... and on it goes. As they are unlikely to ever be implemented, the only function such prioritization exercises serve is to justify environmental

\footnotetext{
${ }^{6}$ It is worth noting how some prioritization exercises have deliberately skewed the selection of the "right bits," away from those sites that have high timber volumes, or productive soils, so as to not constrain development - yet by doing so guaranteeing that the endpoint, if these plans were ever followed, would be akin to that of the West protecting the bits no one with money wants.

${ }^{7}$ Why would the forces that destroyed the rest stop at the PA boundaries? Loggers have access to around 20\% of the "protected forests" and the miners to most of them (Shearman and Bryan, 2011).
} 


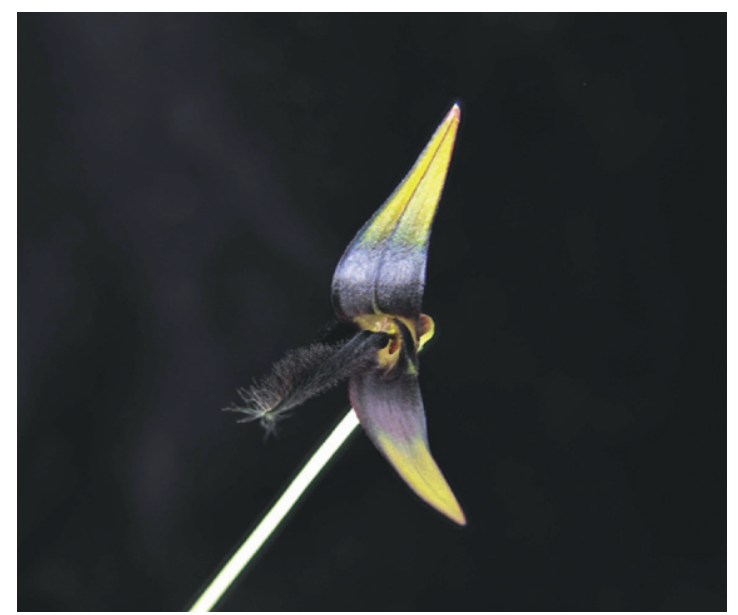

Figure 23.2 Bulbophyllum polyblepharon, an orchid species known only from three localities now within a logging concession in Madang Province. The flower is $12 \mathrm{~mm}$ high and has a metallic iridescence. Prior to 2010, the species was last recorded or examined with scientific intent by Rudolph Schlecter in 1913. There are probably about 3500-4000 species of orchids recorded in PNG, with an estimated 700-1200 of them yet to be described. Between 90 and $95 \%$ of these species are endemic. Of those that have been described, more than $60 \%$ are known from only one or two collections. For the majority, we don't know if they are common and poorly collected, or rare and restricted. This paucity of knowledge is not going to be rectified within the time period in which decisions regarding which regions to keep and which to destroy are made.

degradation of areas outside those identified as worthy of protection. But maybe one should not be worried because there is little chance of any of these plans being implemented anyway, even despite recent DEC fantasies as to financing compulsory land acquisitions with carbon money.

In thinking about PNG's environmental future, I keep coming back to the "enclave" model of development discussed widely in the 1970s and 1980s, but now all but forgotten. In this model, it was recognized that some areas would need to be sacrificed to generate the money necessary to invest in the well-being of people, the only true application of the word "development". Back in the 1970s and 1980s, it was sensible and realistic. But if the money is not applied to such ends, instead siphoned off, wasted, or stolen, while turning ever greater areas into "enclaves" in the hope that more will be used for the right purposes, either insanity, corruption, or both have prevailed.

The majority of people in PNG are not benefiting from the flood of resource cash now lapping at its shores. Tragically, they are going to receive a lesser share in the future as the efficiency of theft improves. As there is more money around, paradoxically the number of people involved in its interception increases, and those already involved become more serious in their efforts. Papua New Guineans are a resilient and resourceful people - the lot of the majority can be improved dramatically by the provision of basic services, allowing them to retain a rural existence while not watching their children die from preventable diseases or not having the educational opportunities much of the world now takes for granted. But their future is dependent on a decent environment: this is perhaps more important in PNG than for many of the world's other peoples. The current trajectory of ever more mines, logging concessions, and speculative opportunism coupled with greater efficiency in stealing is a tragedy that could have been avoided, and maybe still can. PNG is rich enough to not have to make the same choices that other less fortunate countries have had to make - it could keep most of its environments intact and have a decent quality of life for its people, but it desperately needs new leaders who can set a course for a different horizon without personal enrichment as their primary objective. Only then it seems can the state reengage with local people through initiatives to manage the environment, both directly and in the honest application of PNG's environmental laws.

\section{REFERENCES}

Angelsen, A. (1999) Agricultural expansion and deforestation: modelling the impact of population, market forces and property rights. Journal of Development Economics, 58, $185-218$.

Dowie, M. (2009) Conservation Refugees, The Hundred-Year Conflict between Global Conservation and Native Peoples. The MIT Press, Cambridge, MA.

Mack, L. and West, P. (2005) Ten thousand tonnes of small animals: wildlife consumption in Papua New Guinea, a vital resource in need of management. Resource Management in Asia-Pacific Working Paper no. 61, Resource Management in Asia-Pacific Program, Research School of Pacific and Asian Studies, Australian National University, Canberra, Australia. 


\section{Conservation Biology}

Population Reference Bureau (2012) World Population Data Sheet 2012. http://www.prb.org/pdf12/2012-populationdata-sheet_eng.pdf (accessed March 19, 2013.

Shearman, P. L. and Bryan, J. (2011) A bioregional analysis of the distribution of rainforest cover, deforestation and degradation in Papua New Guinea. Austral Ecology, 36, 9-24.

Transparency International (2012) Corruption Perceptions Index 2012. http://www.transparency.org/research/cpi/ overview (accessed 27 March 2013). 